\title{
ASPEK HUKUM ISLAM TENTANG KEKERASAN TERHADAP PEREMPUAN
}

\section{Oleh : Mutmainah}

\begin{abstract}
ABSTRAK
Sejarah peradaban manusia, perempuan selalu mendapatkan perlakuan yang tidak adil dari kaum laki-laki. Perempuan hanya dijadikan manusia pelengkap, manusia kelas dua (the sechon humanity), bahkan dalam banyak kasus kita lihat perempuan tidak jarang diperlakukan sebagai pemuas nafsu belaka. Perlakuan yang diskriminatif dan subordinatif terhadap perempuan ini turut dilanggenggkan melalui hokum-hukum (doktrin-doktrin) agama, sehingga tak jarang agama dijadikan tameng untuk membenarkan tindak kekerasan terhadap perempuan .

Hukum Islam yang bersumber dari Al-Qur'an dan Hadits-hadits Nabi, bertujuan memelihara dan menjaga kemaslahatan umat manusia, dan menjunjung tinggi martabat manusia tanpa melihat jenis kelamin apakah dia laki-laki ataupun perempua. Oleh karena itu, hokum islam tidak membenarkan sama sekali segala bentuk tindak kekerasan terhadap seseorang, apalagi jika kekerasan itu dikakuan hanya karena jenis kelaminnya perempuan. Melalui tulisan ini penulis dengan sengaja mencoba membahas mengenai aspek hokum islam tentang kekerasan terhadap perempuan. Hal ini dilakukan, Karena melihat fenimena-fenomena sekarang dimana begitu banyak perempuan mengalami tindak kekerasan, baik kekerasan fisk ataupun non fisk, meupun kekerasan sikologis dari pihak laki-laki.
\end{abstract}

Kata kunci: Hukum Ilam, Kekerasan Perempuan, kedalam Penelitian.

\section{A. Pendahuluan}

Kekerasan adalah bentuk kejahatan yang dilakukan oleh seseorang tanpa ada belas kasihan. Sebuah fenomena yang berkembang sekarang adalah tindak kekerasna merupakan sebuah gejala yang telah menjangkiti masyarakat dunia. Pada konteks yang lebih umum, kekerasan terhadap perempuan menjadi perbincangan yang terus mengemuka ahir-ahir ini. Banyak fakta dalam masyarakat kita yang menunjukan, bahwa banyak pihak-pihak perempuan yang menjadi korban kekerasan dari pihak laki-laki tanpa ada rasas kemanusiaan. Perempuan, menurut banyak laporan menempati posisi yang rentan terhadap terjadinya tindakan kekerasan tersebut, seperti pelecehan seksual, pemerkosaan, dan utamanya mengalami tindak kekerasan 
dalam lingkungan Rumah tanggga, baik dalam keluarga inti maupun dalam keluarga yang diperluas, dimana korbannya dapat merupakan isteri, anak, atau Pembantu Rumah Tangga yang bentuk-bentu kekerasannya pun bervariasi dari kekerasan fisik atau kekerasan non fisik. Kekerasan seksual, maupun pencedraan pisikologis.

Tindak kekerasan terhadap perempuan tersebut, merupaka salah satu tindakan pelanggaran terhadap hak-hak seorang perempuan, yang sampai saat ini masih kita jumpai dimana-mana: di dalam Rumah Tangga, di lingkungan kerja, dalam lingkungan social, dan dalam kehidupan bernegara.

Menyikapi berbagai tindak kekerasan terhadap perempuan tersebut, maka yang menjadi pertanyaan kita sekarang bagaimana Al-Qur'an (Hukum Islam) memandang berbagai tindakan kekerasan terhadap perempuan ini?.

\section{B. Pembahasan}

I. Perempuan dan kekerasan

Kekerasan terhadap perempuan kini telah terbuka sebagai fakta-fakta nyata, baik dalam skala regional, nasional, maupun internasional. Fenomena social tentang kekerasan terhadap perempuan ini dapat kita baca dari banyak media masa local maupun nasional setiap hari. Disamping itu, kita juga dapat membaca kenyataan ini dari data-data lapangan yang dilaporkan oleh lembaga-lembaga social yang memfokuskan kerjanya pada upaya penghapusan kekerasan terhadap perempuan. Dari sumber-sumber informasi tersebut kita mencatat, bahwa fenomena kekerasan terhadap perempuan ternyata telah memasuki ruang publik dalam bentuknhya yang beraneka ragam dan melibatkan banyak pihak, pribadi-pribadi, lembaga siosial, maupun Negara.

Oleh karena itu, fenomena semakin marak terjadinya bentuk-bentuk tindak kekerasan terhadap perempuan ini memerlukan perhatian yang serius dari kita semua. Banyak perempuan mengalami tindak kekerasan, baik itu dalam rumah tangga maupun tempat-tempat yang lain. Sebagai contoh kekerasan yang sangant merebak sekarang ini terdapat perempuan adalah kasusu perdagangan perempuan (trafficking) yang lebih banyak mengorbankan anak perempuan di bawah umur, mereka dijadika objek perkosaan, dicabuli, dan kemudian diperdagangkan. Contoh lainnya adalah bentuk kekerasan dalam Rumah Tangga, seperti adanya perkosaan suami terhadap istri, pemukualn dan penganiayaan, majikan yang memeperkosa pembantunya, seorang istri yang 
harus menanggung beban batin akibat suaminya kawin lagi (berpologami)nyang akhir-akhir ini semakin merebak, serta bentuk-bentuk kekerasan lainnyaterhadap perempuan.

Berbagai tindak kekerasan terhadap perempuan tersebu, merupakan tindak pelanggaran hak-hak asasi yang paling kejam terhadap perempuan, sehingga tak salah apabila tindakan ini disebut oleh Perserikatan Bangsa-Bangsa (PBB) sebagai sebuah kejahtan kemanusiaan. Tindak kekerasan ini antara lain, mencakup pelecehan seksual, kekerasan dalam rumah tangga, perkosaan, serta ingkar janji.

\section{Bentuk-bentuk kekerasan Terhadap Perempuan}

Pada dasarnya kekerasan terhadap perempuan adalah segala bentuk perilaku ysng dilakukan oleh pihak pelaku kekerasan yang memunculkan perasaan-perasaan tidak nyaman dan bahkan rasa takut. Perilaku yang tidak diharapkan ini dapat berbentuk kekerasan fisik maupun non fisik. Perilaku tersebut bisa berupa sentuhan, pelukan, ciuman, ataupun paksaan seksual, baik melalui penetrasi pada alat kelamin, anus, ataupun mulut, dengan menggunakan objek. Disamping itu, kekerasan bisa juga berupa ejekan secara verbal atau meremehkan keberadaan perempuan. $^{1}$

Berkaitan dengan tindak kekerasan terhadap perempuan ini, dalam pernyataan dikonfrensi perempuan sedunia ke-4 di Beijing bulan September 1995, Sekertaris Jendral PBB Boutros Boutros Ghali mengatakan "kekerasan Terhadap Perempuan adalah masalah universal pula" tetapi masalah ini terus bertambah parah. Pada tahun 1993, sidng umum PBB mengakui secara eksplisit adanya kekerasan terhadap perempuan yang semakin menghawatirkan dan oleh karena itu, di angkatlah "Deklarasi Penghapusan Kekerasan Terhadap Perempuan", dimana disebutkan dalam salah satu pasalnya, yakni pasal 2 bahwa bentuk-bentuk kekerasan terhadap perempuan dapat dikategorikan sebagai berikut:

1. Kekerasan secara fisik, seksual, dan pisikologis yang terjadi di dalam keluarga, kekerasan mewujud dalam tindakan-tindakan seperti: pemukulan, penyalahgunakaan seksual atas perempuan kanak-kanak dalam rumah tangga, kekerasan yang berhubungan dengan maskawin, pemerkosaan dalam perkawinan, pengerusakan alat

\footnotetext{
1 Siti Aris Purnama dalam Pemahaman Bentuk-bentuk TIndak Kekerasan Terhadap Perempuan Dan alternative Pemechannya (Jakarta : Alumni, 2000), h. 113
} 
kelamin perempuan, dan praktek-prakter kekejaman tradisional lain terhadap perempuan, kekerasan diluar hubungan suami istri, serta kekerasan yang berhubungan dengan eksploitasi tubuh dan tenaga manusia (terutama anak-anak dan wanita).

2. Kekerasan secara fisik, seksual, dan psikoligis yang terjadi dalam masyarakat luas, beberapa tindakan yang bisa disebut kekerasan adalah perkosaan, penyalahgunaan seksual, pelecehan dan ancaman seksual d tempat kerja, dalam lembaga-lembaga pendidikan, dan sebagainya, perdagangan perempuan, dan pelacuran paksa.

3. Kekerasan secara fisik, seksual, dan psikologi yang dilakukan dalam lingkup Negara, resolusi itu menganggap bahwa Negara bisa disebut pelaku kekerasan, juka ia melakukan atau membenarkan tindak kekerasan, baik secara fisik, seksual, maupun psikologis. $^{2}$

Selain bentuk-bentuk kekerasan terhadap perempuan menurut deklarasi PBB tersebut, menurut Poerwandari kristy, kekerasan terhadap perempuan secara umum dapat dijabarkan pula sebagai berikut:

1. Kekerasan fisik, seperti memukul, menampar, mencekik, menendang, melempar barang ketubuh korban, menginjak, melukai dengan tangan kosong atau alat/senjata serta membunu. Dampak dari kekerasan fisik ini dapat berupa rasa sakit, cacat fisik,bahkan sampai ke kematian.

2. Kekerasan psikologis, yang termasuk kekerasan psikologis antara lain: berterikateriak, menyumpah, mengancam, merendahkan, mengatur, melecehkan, menguntip dan memata-matai, tindakan-tindakan lain yang menimbulkan rasa takut (termasuk yang diarahkan kepada orang-orang dekat korban, misalnya keluarga, anak, suami, teman dekat, dll). Dampak dari kekerasan psikologis adalah perasaan terancam, tidak aman, tidak terlindungi, perasaan khawatir, cemas, dan takut. Pada tahap lanjut, bisa berkembang menjadi trauma yang mengahalangi dan menghambat aktifitas keseharian.

3. Kekerasan seksual, yaitu : melakukan tindakan yang mengarah ke ajakan/ desakan seksual, seperti pelecehan seksual terhadap anak'anak dan pembantu rumah tangga, percumbuan dengan pembantu, penyimpangan perilaku seksual, seperti menyentuh,

\footnotetext{
2 Dadang S Anshori, Membincangkan Feminisme Refleksi Muslimah Atas Peran Sosial Kaum Wanita, (cet I; Bandung: Pustaka Hidayat, 1997), h. 66-67
} 
meraba, mencium, dan/atau melakukan tindakan-tindakan yang tidakn di kehendaki korban, memaksa korban menonton pornografi, gurawan-gurawan seksual yang tidak dikehendaki korban, ucapan-ucapan yang merendahkan dan melecehkan dengan mengarah pada aspek jenis kelamin/seks korban, memaksa berhubungan seks tanpa persetujuan korban dengan kekerasan fisik maupun tidak memaksa melakukan aktifitas-aktifitas yang tidak disukai, merendahkanmenyakiti atau melukai korban, pornografi (dengan dampak social) yang sangat luas bagi perempuan pada umumnya). Dampak dari kekerasan seksual adalah trauma, hilangnya keperawanan anak perempuan, atau pembantu perempuan, termasuk kehamilan yang tak di inginkan oleh korban perkosaan.

4. Kekerasan financial, yang termasuk kategori ini adalah mengambil uang korban, menahan atua tidak memberikan pemenuhan kebutuhan financial korban, mengendalikan dan mengawasi pengeluaran uang sampai sekecil-kecilnya, semuanya dengan maksut untuk dapat mengendalikan tindakan korban.

5. Kekerasan spiritual, yang dimaksut dengan kekerasan spiritual iyalah: merendahkan keyakinan dan kepercayaan korban memaksa korban meyakini hal-hal yang tidak diyakininya memaksa korban mempraktekan ritual dan keyakinan tertentu. ${ }^{3}$

Dari beberapa bentuk-bentuk kekerasan terhadap perempuan yang di uraikan di atas, yang umum terjadi adalah pelecehan seksual dalam bentuk-bentuk gurauan-gurauan porno, komentar-komentar tentang bentuk tubuh perempuan yang mengobjekkan, merendahkan, dan mengarah kepada pemikiran sksual, Sentuhan-sentuhan yang tidak dikehendaki, sampai pada pemaksaan melakukan tindakan seksual. Tindak kekerasan dapat secara lagnsung dikaitkan dengan ancaman terhadap posisi kerja perempuan, dapat pula tidak langsung dikaitkan dengan posisi formal, tetapi memunculkan ketakutan dan dampak-dampak psikologis, fisik, dan social bagi korban, Disamping pelecehan seksual, sering kali juga terjadi perkosaan, perdagangan perempuan (trafficking), kekerasan yang dilakukan pacar dan penganiayaan umum, pelecehan seksual pada perempuan di tempat kerja, lembaga pendidikan, dan lain-lain.

\footnotetext{
${ }^{3}$ Siti Ari Purnama dalam Pemahaman Bentuk-bentuk Kekerasan Perhadap Perempuan Dan alternative Pemecahannya (Jakarta: Alumni, 2000), h. 12
} 


\section{Faktor-Faktor Yang Mempengaruhi Kekerasan Terhadap Perempuan.}

Dalam proses sejarah, Gejala kekersan (Violence), kebiadaban (barbarity), kekejaman (cruelty), dan segalah bentuk tindakan yang tidak melampawi batasan kemanusiaan (inhumanity), muncul dalam berbagai segi kehidupan umat manusia itu sendiri.

Menurut Mansur Faqih, bahwa sumber serta alasan-alasan yang menyebabkan terjadinya kekerasan terhadap sesame manusia sangatlah beragam, seperti politik, keyakinan keagaman, atau bahkan rasisme.

Selain itu bila ditelaah dari sisi psikologi, terdapat tiga factor yang menyebabkan terjadinya tindakan kekerasan terhadap perempuan, dimana dua penjelasam pertama merupakan "Penjelasan Konvensional" yang mengacu pada sisi internal pelaku dan korban, sedangkan penjelasan ketiga adalah "penjelasan psikologis feministik" yang melihat keterkaitan erat antara erat antara struktur social dan pembagian kekuasaan dalam masyarakat dengan dan dampaknya terhadap aspek internal individu.

Adapun tiga factor psikologis yang menyebabkan terjadinya tindak kekerasan tersebut, yaitu:

1. Penjelasan yang mengarah ke kondisi internal, karakteristik pribadi atau psikopatologi pelaku kekerasan, yang menyebabkan kekerasan kemudian terjadi. Misalnya, bahwa kekerasan dilakukan oleh orang-orang yang terganggu, tertekan, memiliki banyak konflik dan masalah, yang kemudian direspon dengan cara melakukan kekerasan pada orang-orang disekitarnya. Pandangan ini biasanya menyatakan, bahwa kekerasan terhadap perempuan bukan merupakan hal umum, melainkan hal sangat kusus atau kasuistik.

2. Penjelasan yang mengarah ke alasan-alasan yang diletakan ke karakteristik pribadi korban kekerasan. Masuk dalam bagian ini adalah penjelasan bahwa kejadina kekerasan diprovokasi oleh korban, misalnya dengan tingkah lakunya yang mengundang, atau bahwa korban memiliki karakteristik kepribadian tertentu yang menyebabkan muda mengalami kekerasan.

3. Penjelasakn feministic, yaitu kekerasan terhadap perempuan merupakan produk struktur social dan sosialisasi dalam masyarakat yang mengutamakan dan menomor 
satukan kepentingan dan perspektif laki-laki, sekaligis menganggap perempuan sebagai jenis kelamin yang lebih rendah dan kurang bernilai dibandingakn dengan laki-laki. Pandangan ini menyatakan bahwa kekerasan terhadap perempuan merupakan suatu hal yang cukup umum terjadi sebagai consensus strukturmasyarakat yang mementingkan dan didominasi oleh laki-laki (Poerwandari Kristi dalam Saparina Sadli, 2000:18)

Bertolak dari kedua pandangan di atas, baik pandangan konvensional maupun pandangan feminis pada akhirnya dapat disimpulkan, bahwa alas an dari situasi perempuan menjadi korban kekerasan laki-laki mencakup interaksi kompleks dari aspek biologi sosio cultural, ekonomi, psikologi, dan politis, yaitu :

1. Laki-laki secara fisik lebih kuat dan pada perempuan, dan terdapat kemungkinan tingkat agresivitas yang lebih tinggi memiliki dasar biologis pula. Dalam msyarakat, laki-laki juga dibiasakan untuk melatih dan menggnakan fisiknya, sekaligus berkelahi, menggunakan senjata, dan menggunakan intimidasi kekuatan sejak masa kanak-kanak.

2. Dalam masyarakat terdapat tradisi panjang mengenai dominasi laki-laki terdapat perempaun, dan toleransi penggunaan kekuatan oleh laki-laki. Tradisi tersebut juga terampilkan dari film, pornografi, music rock, dan media pada umumnya.

3. Realitas ekonomi memaksa perempuan untuk menerima penganiayaan dari orang pada siapa dia bergantung.

4. Pada tingkat individu, factor psikologis berinteraksi dengan hal-hal yang telah disebutkan di atas untuk menjelaskan, bahwa sebagai laki-laki melakukan kekerasan dan sebagian perempuan menjadi korban kekerasan; sementara sebagai laki-laki yang lain tidak melakukan kekerasan tersebut dan sebagian perempuan lain tidak menjadi sasaran kekerasan.

Berdasarkan uraian di atas, dapat dilihat stigma social yang dilestarikan oleh mitos-mitos seputar identitas korban serta pelaku, menyuburkan kondisi kekerasan terhadap perempuan sebagai sebuah wilayah buram dan dianggap sukar untuk diungkap. Akibatnya, banyak korban merasa enggan untuk menceritakan pengalaman pahitnya ini, bahkan pada anggota kekeluargaannya sendiri. 


\section{Kekerasan Terhadap Perempuan Menurut Hukum Islam.}

Tatanan kehidupan umat manusia yang didomisili kaum laki-laki atas kaum perempuan sudah menjadi akar sejarah yang panjang Sejarah dunia mencatat betapa perempuan sering kali diperlakukan secara nista. Pada banyak peradaban besar, seperti Yunani, Romawi, India, dan Cina, dan juga Agama-agama, seperti Yahudi, Nashrani, Budha, Zoroaster, dan sebagainya, semuanya menganggap dan menempatkan perempuan sebagai "setengah manusia", "manusia kelas dua", makhluk pelengkap", dan sebagainya, yang hak dan kewajiban bahkan keberadaan di dunia ditentukan oleh laki-laki.

Dalam peradaban Yunani misalnya, perempuan sepenuhnya berada di bawah kekuasaan ayahnya. Setelah kawin, kekuasaan tersebut panda ke tangan suami. Kekuasaan ini mencakup kewenangan menjual, mengusir, menganiaya, dan membunuh sekalipun. Demikian halnya dengan peradaban Hindu dan Cina yang tak lebih baik dari peradaban Yunani dan Romawi. Dalam masyarakat hindu, hak hidup seorang wanita yang bersuami harus berakhir pada saat kematian suaminya. Isteri harus dibakar hidup-hidup pada saat mayat suaminya dibakar, sedangkan dalam masyarakat Cina terdapat petuah-petuah kuno yang tidak memanusiakan perempuan. ${ }^{4}$

Hal yang sama juga terjadi pada masyarakat arab pra islam (jahiliyah), dimana dalam tradisi masyarakat tersebut menghalalkan dibunuhnya seorang bayi hanya karena ia terlahir sebagai perempuan. Setelah menikah, perempuan menjadi hak penuh suami dan keluarganya. Ketika suaminya meninggal, ia tidak bisa menjadi pewaris melainkan benda yang diwariskan (Hasher Fuad, 1996:73)

Ilustrasi yang memilukan di atas, menggambarkan kepada kita betapa perempuan selalu menjadi korban kekerasan dari masa ke masa. Dalam bentuk yang tidak persis sama, kekerasan terhadap perempuan terus terjadi sampai kini.

\footnotetext{
${ }^{4}$ M. Quraish Shihab, Wawasan Al-Qur'an Tafsir Maudu'I Atas Pelbgai Persoalan Ummat (cet II; Bandung : Mizan, 1996), h. 296
} 
Fakta bahwa perempuan banyak mengalami perlakuan-perlakuan nista dan mengalami berbagai bentuk kekerasan dari laki-laki, menuntut kita untuk lebih arif lagi dalam menyikapi, khususnya melihat lebih kedalam lagi bagaimana sesungguhnya hokum islam memandang semua bentuk kekerasan terhadap perempuan tersebut.

Islam adalah agama yang membawa misi yang luhur, yaitu Rahmatan lil 'alamin (Pembawa kebahagiaan bagi sekalian alam), sekaligus sebagai agama tauhid yang menyadari bahwa yang patut disembah adalah Allah SWT, selain Dia semua hanyalah mahluk belaka membawa pembebasan bagi manusia pada umumnya dan perempuan pada khususnya dari segala bentuk penindasan, belenggu, dan penyembahan. Islam mengajarkan bahwa semua manusia adalah mahluk ciptaan Allah SWT dan sama kedudukannya di hadapan Allah SWT. Dengan demikian islam membawa kepada ajaran egalitarian atau persamaan antar manusia, dimana antara laki-laki dan perempuan adalah sama tidak ada perbedaan. Satu-satunya perbedaan yang memungkinkan seseorang menjadi lebih tinggi atau lebih renda derajatnya dari pada manusia lainnya adalah nilai pengabdian dan ketaqwaannya kepada Allah SWT. Sebagaiana firmannya dalam surat al-hujurat (49) : 13 berikut;

Artinya: Hai manusia sesungguhnya kami menciptakan kamu dari seorang laki-laki dan seorang perempuan dan menjadi kamu berbangsa-bangsa dan bersuku-suku, supaya kamu saling kenal-mengena. Sesungguhnya orang yang paling mulia diantara kamu sisi Allah adalah orang yang paling bertaqwa diantar kamu. Sesungguhnya Allah maha mengetahui lagi maha mengenal.

Oleh karena itu, Islam memandang bahwa kekerasan terhadap perempuan, merupakan suatu tindakan yang melanggar hokum atau syariat Islam.

Dalam hokum islam yang sebagian besarnya bersumber dari wahyu Tuhan dan Sunnah Nabi, di lihat dari konteks praktik jahiliyya, merupakan suatu revolusi, karena Al-Qur'an sebagai salah satu sumber hokum islam sangat meningkatkan status social perempuan dan meletakan norma-norma yang jelas, sebagai penentuan terhadap adat dan kebiasaan yang memperlakukan perempuan sebagai suatu yang di perdagangkan atau sebagai objek napsu seksual. Disamping itu, dalam Al-Qur'an juga menanamkan norma-norma yang pasti dan memberi perempuan status yang jelas, meskipun tidak secara persis setara dengan laki-laki. 
Banyak ayat Al-qur'an sebagai salah satu sumber hokum islam yang berbicara tentang kekerasan terhadap perempuan. Sebagai contoh, menyangkut persoalan kekerasan fisik dan seksual, Al-Qur'an berbicara mengenai pemukulan terhadap isteri yang nusyuz, mengeksploitasi perempuan untuk menjadi pekerja seks, dan larangan melakukan pelecehan seksual. Menyangkut persoalan kekerasan psikis, Al-Qur'an berbicara tentang larangan melakukan adalah dan memperlakukan perempuan sebagai benda warisan. Samentara menyangkut masalah kekerasan ekonomi, Al-Qur'an dengan tegas memberikan perempuan hak pemilikan dan pengaturan harta.

\section{Kekerasan Fisik dan Seksual}

a. Pemukulan Terhadap Isteri yang Nusyuz.

Banyak literatur islam menyatakan, bahwa memukul isteri diperbolehkan, bahwa memukul isteri adalah cara yang dianjurkan Al-Qur'an untuk memberi pelajaran isteri yang nusyuz (meninggalkan rumah tanpa izin atau berbuat "melawan" suami). Ayat yang dijadikan dasar pemikiran itu adalah Q,S An-Nisa' (4): 34 yang berbunyi:

Artinya: par isteri yang kamu khawatirkan nusyuznya maka nasihatilah mereka dan pisakanlah mereka di tempat tidur mereka, dan pukullah mereka. Kemudian jika mereka menaatimu, maka janganlah kamu mencari-cari jalan untuk menyusahkannya. Sesungguhnya AllahM aha Tinggi lagi Maha Besar. Q.S. An_Nisa', (4): 34.

Secara sepintas ayat ini tampak membolehkan pemukulan terhadap isteri. Namun demikian, pernyataan Al-Qur'an yang menjadikan pemukulan sebagai alternative terakhir bagi suami yang isterinya nusyuz tidak boleh dipahami sebagai anjuran untuk berbuat kekerasan terhadap perempuan. Sebab, dalam ayat yang sama dikemukakan cara yang lebih utama dan efektif ketimbang pemukulan itu sendir, yakni mmberikan nasihat yang baik (mauizhah) dan pisah yang ranjang.

Memberikan nasihat yang baik (mauizhah) dan pisah ranjang sunggu merupakan metode jitu yang diperkenalkan Al-Qur'an untuk meminimalisir tindak kekerasan berupa pemukulan. Dalam konteks social budayah yang begitu permisif terhadap kekerasan, kedua metode yang dikemukakan ayat ini benar-benar menawarkan suatu yang melawan arus sekaligis mengakomodir kepentingan perempuan. 
Semangat menghindari pemukulan akan semakin jelas pula, jika kitamenelaah hadits Nabi berikut ini:

Artinya : dari Abu Hurayrah Ar-Raqqasyi dari pamannya, Nabi SAW bersbda : jika kalian kawatir isteri kalian nusyuz, pisah ranjanglah dengan mereka H.R Abu Dawud. ${ }^{5}$

Disamping hadits tersebut diatas, dalam hadits riwayat Abu Dawud yang lain Nabi bahkan menolak orang yang ingin bertanya tentang pemukulan isteri. Melalui Umar bin Khattab, Rasulullah SAW Bersabda :

Artinya : Janganlah seorang suami bertanya dalam hal apa ia (boleh) memukul isterinya (H.R. Abu Dawud). ${ }^{6}$

Berdasarkan ayat Al-Qur'an dan hadits diatas sebagai sumber hokum islam kita melihat, bahwa pada hakikatnya Islam tidak menghendaki terjadinya pemukulan isteri olehn suami.

\section{b. Larangan mengeksploitasi Perempuan Untuk Menjadi Pekerja Seks}

Di era sekarang ini kita melihat trafficking atau perdagangan perempuan adalah suatu fakta yang banyak terjadi terutama di kota-kota besar. Banyak cara yang dilakukan untuk memaksa perempuan terseret masuk kedalam. Namun, dari berbagai cara dan dalihada satu tujuan utama dari prektek ini, yakni menggerak keuntungan material dengan menjadikan tubuh perempuan sebagai umpan. Trafficking telah membuat perempuan menderita jiwa dan raga, lahir dan batin.

Fenomen kasus trafficking yang terjadi saat ini bukan sesuatu yang baru, praktek seperti ini perna terjadi pula pada masa lalu, yakni pada masa Rasulullah SAW, dimana pada masa itu ada seseorang budak perempuan mukmina yang dijual majikannya kepada seorang quraisy dengan motif, jika perempuan tersebut hamil dan melahirkan anak, maka laki-laki tersebut akan menebusnya dengan jumlah tertentu. Menyikapi hal ini, maka perempuan tersebut mengadukan kepada Rasulullah SAW, yang serta merta pengaduan ini mendapat tanggapan dari langit dan menjadi sebab turunnya ayat 33 Surah an-Nur:

\footnotetext{
${ }^{5}$ Abu Dawud, Sunan Abu Dawud, (Beirut : Dar Fiqr), h 224

${ }^{6}$ Ibid., h.246
} 
Artinya: dan janganlah kamu paksa budak-budak perempuan kamu untuk melakuka pelacuran sementara mereka sendiri ingin menginginkan kesuian, karena kamu hendak mencari keuntungan duniawi..." (Q.S an-Nuur, 24)

Dari ayat di atas, jelas bahwa Al-Qur'an berpihak pada "pemberontakan perempuan" yang berani menentang atasannya yang ingin mengeksploitasi dirinya. Al-Qur'an turun dengan membela perempuan sekalipun ia berstatus budak dan menjamin hak semua perempuan untuk melakukan kontrol atas tubuh dan dirinya sendiri. Ini berbarti, bahwa eksploitasi seks terhadap perempuan siapa pun orangnya dan apa pun agamanya adalah hal yang sangat dikutuk tuhan.

Dewasa ini kita melihat fenomena eksploitasi seks tidak saja terjadi pada perempuan dewasa yang memiliki persoalan ekonomi, keluarga, maupun persoalan social lainnya, melainkan terjadi juga pada anak-anak dibawa umur yang tanpa dosa dan sama sekali tidak sadar bahwa dirinya sedang menjadi sasaran eksploitasi, yang kian hari jumlah mereka kian meningkat.

Menyikapi semua ini, maka kita sebagai masyarakat memberikan empati terhadap para korban tersebut, diantara dengan bersikap:

Pertama: bersikap tegas terhadap pelaku eksploitasi seks, dengan cara mencegah, menolak, dan menghentikan eksploitasi sesuai dengan kemampuan dan wewenang yang dimiliki. Melihat kasus perdagangan perempuan (trafficking) dan eksploitasi seks sudah menjadi semacam mafia, maka diperlukan lembaga-lembaga yang kuat bekerja secara terkordinir dan sistematis untuk emgnhentikan praktek pemaksaan tersebut.

Kedua: bersikap lapang dada, luas ampunan, menunjukan empati dan kasih saying terhadap mereka yang di lacurkan atatu dijebak dalam eksploitasi seks. Sikap inilah yang seharusnya menjadi sikap masyarakat, bukan malah ikut memberikan cap negative yang kian memperparah penderitaan korban. Sikap seperti itu sama sekali tidak mengikuti tuntutan Allah SWT. Yang jelas menyatakan, bahwa ia Maha pengampun dan Maha Pengasih pada korban yang dipaksa itu. Sebagaimana firmanNya :

Artinya: dan barang siapa yang memaksa mereka, maka sesungguhnya Allah setelah keterpaksaan mereka it, Maha Pengampun lagi Maha Pengasih (Q.S an-Nuur : 33 


\section{c. Larangan melakukan pelecehan seksual dan zina}

Dalam Al-Qur'an, pelecehan seksual tidak semata-mata berarti menggoda, berkata jorok, berbuat tidak senonoh, atau melakukan pemerkosaan terhadap perempuan. Lebih dari itu semua, pelecehan seksual juga berarti pelanggaran terhadap nilai-nilai seksual yang luhur.

Cara pandang Al-Qur'an terhadap seksualitas memasukan unsure normal dan tidak semata-mata bertumpuk pada perasaan individu yang bersangkutan, maka zina dan perselingkuhan yang dilakukan atas dasar suka sama suka pun termasuk kategori pelecehan seksual, dan sesungguhnya perbuatan yang mengarah pada zina, apalagi zina itu sendiri dilarang. Dalam Surah al-Isra' Allah SWT berfirman

Artinya: dan janganlah kamu mendekati zina; sesungguhnya zina itu adalah suatu perbuatanyang kejih dan suatu jalan yang buruk. Q.S al-isra: 32

Bertolak dari ayat diatas, kita melihat bahwasanya ayat ini berisi larangan terhadap zina dan apasaja yang mengarahkepada zina, seperti memandang lawan jenis dengan penuh syahwat, berduaan ditempat sepi, meraba, mengelus, kencan dengan pasangan yang bukan muhrim, dan sebagainya.

Diantara tujuan syari'at islam adalah untuk memelihara kehormatan dan harga diri manusia, dan memelihara kesucian keturunan dan hak reproduksi. Karena itu, haramnya perbuatan zina dan semua perilaku pelecehan seksual tersebut ditujukan, baik kepada perempuan maupun laki-laki. Dengan demikian, tidak ada indikasi yang menyiratkan perempuan sebagai penyebab terjadinya perbuatan zina, melainkan laki-laki pun ikut terlibat didalamnya.

Sebagai contoh, banyak kjadian menunjukan bahwa terjadinya pelecehan seksual, kususnya pemerkosaan, lebih disebabkan oleh nait buruk yang suda tersimpan dalam benak lakilaki, pada umumnya dalam kasusu pemerkosa telah merencanakan perbuatannya dengan matang. Selain itu, dalam banyak kasusu perkosaan juga tidak memandang usia, bisa menimpah balita maupun manula. Kenyataan ini menunjukan kepada kita, bahwa kebanyakan dalam kasus pelecehan seksual, perempuan menjadi korban, dan tidak seperti anggapan kebanyakan orang bahwa perempuan adalah penyebab terjadinya pelecehan seksual. 


\section{a. Kekerasan psikis}

Larangan melakukan adhal dan memperlakukan perempuan sebagai benda warisan

Menurut Munawir, secarah harfiah adalh berarti menekan, mempersempin, dan menghalang-halangi kehendak oranglain. Dalam Al-Qur'an secara jelas dinyatakan haram berbuat adhal kepada perempuan. Allah SWT berfirman:

Artinya: Hai orang-orang yang beriman tidak halal bagi kamu mempusakai perempuan dengan jalan paks, dan janganlah kamu menyusahkan merekakaren hendak mengambil kembali sebagian dari apa yang telah kamu berikan kepadanya, kecuali bila mereka melakukan pekerjaan keji dan nyata... Q.S an-Nisaa' :19

Artinya: apakah kamu mentalak isteri-isterimu lalu habis massa iddahny, maka janganlah (para wali) menghalangi mereka kawin lagi dengan suaminya apabila terdapat kerelaan diantara mereka dengan cara yang ma'ruf. Q.S al-Baqarah 232

Berdasarkan ayat-ayat diatas, kita dapat melihat bahwa adanya pelarangan adhal terhadap perempuan, baik terhadap perempuan yang ditinggal mati suaminya maupun terhadap perempuan yang cerai hidup.

Dalam beberapa hal, praktek adhal yang paling banyak terjadi adalah dalam rumah tangga, yang justru banyak menimpa perempuan yang bersuami, dimana mereka disakiti dan disia-siakan dalam pergaulan suami isteri. Disamping itu pula, adhal sering dilakukan dengan membuat isteri tidak memiliki akses ekonomi ke luar, sehingga sepenuhnya tergantung pada suami dan dengan demikian suami menguasai seluruh aspek ekonomi keluarga, menciptakan kondisi yang penuh ancaman, ketakutan, dan kekalutanm sehingga isteri tidak berani mengungkapkan kekerasan, kezaliman, dan berbagai tindakan yang menimpahnya.

Selain terjadinya praktek adhal dalam rumah tangga yang banyak menimpa perempuan yang bersuami, sekarang ini praktek adhal berupa pemaksaan perempuan dalam memilih jodohnya pun masih banyak terjadi. Hak perempuan untuk menentukan nasip dirinya sendiri apakah ia akan melajang atau menikah masih sering terpasung. Alas an perjodohan ini diantaranya terjadi karena alasan rasa malu si perempuan atau dari pihak orang tua sendiri yang 
takut anaknya dikatakan perawan tua, janda kesepian, atau bahkan demi memenuhi kebutuhan dan ambisi ekonomi orang tuan dan keluarga seta kepentinga social.

Pemasung terhadap hak peremuan untuk memilih calon suaminya sendiri ini, merupakan salah satu bentuk kekerasan psikis yang tidak sejalan dengan nilai-nilai Islam. Dama Islam, perempuan dipandang sebagai individu yang betanggung jawab atas dirinya sendiri dan bukan komoditas yang ditentukan oleh orang atau mesyarakat di luar dirinya.

Demikianlah Islam mengharamkan secara tegas praktek-praktek mewarisi perempuan, menikahkan perempuan dengan paksa, dan memeras perempuan. Islam menempatkan perempuan pada jerajat kemanusiaannya sebagai bani Adam yang setara dengan laki-laki. Islam dengan demikian, mengakui hak perempuan untuk menentukan nasipnya sendiri sekaligus melindungi perempuan dari tindakan pemaksaan dari orang lain.

\section{b. Kekerasan Ekonomi}

Hak perempuan atas harta yang dimiliki

Dalam pandangan islam, perempuan diakui mempunyai hak milik pribadi, baik yang didapati dari usahanya sendiri, pemberian orang lain, atau pemberian suami. Suami tidak berhak mengutak-atik hak milik pribadinya isterinya itu, kecuali seizing isteri dalam status diceraikan pun, suami sama sekali tidak berhak meminta kembali apa yang telah diberikan kepada isterinya. Allah SWT brfirman :

Artinya : dan jika kamu ingin menggantiisterimu dengan isteri yang lain, sedang kamu telah memebrikan kepadaseorang diantara mereka harta yang banyak, maka janganlah kamu mengambil kembali dari padanya barang sedikitpun. Apakah kamu akan mengambilnya kembali dengan jalan tuduhan dustadan dengan (menanggung) dosa yang nyata. Q.S an-Nisaa' : 20

Pernyataan Al-Qur'an tentang hak milik isteri seperti yang tersirat dalam ayat yang di atas, memang tampak sederhana. Tetapi sesungguhnya kita dapat melihat dengan adanya pengakuan ini Al-Qur'an telah membuka peluang kepada para isteri untuk memiliki akses ekonomi. Namun demikian, meskipun hak milik pribadi demikian, meskipun hak milik pribadi perempuan dijamin, bukanlah berarti islam membuat garis pemisah antara hak milik suami dan isteri. Dalam rangka tolong menolong kebaikan dan ketaqwaan seorang isteri yang memiliki kekayaan dan kemampuan ekonomi yang lebih di anjurkan membuat suaminya. 
Berangkat dari semua uraian-uraian di atas, jelaslah bagi kita bahwa hokum islam yang merupakan formulasi dari hasil ijtihad para fuqaha (ahli hokum islam) yang digali dan dipahami dari Al-Qur'an dan hadits nabi yang secara otomatis menganggap, bahwa kekerasan terhadap perempuanapapun bentuknya harus dihilangkan, karena tindak kekerasan tersebut mendatangkan kemudharatan bagi perempuan. Banyak ayat Al-Qur'an yang mencelah kekerasan terhadap perempuan dengan menggunakan gaya bahasa yang beragam, ada yang menyuruh untuk berbuat baik terhadap perempuan, ada yang melarang praktek-praktek yang merugikan perempuan, ada yang dikemukakan sebagai langkah preventif untuk melindungi perempuan dari tindak kekerasan, ada pula yang dinyatakan sebagai langkah kuratif terhadap praktek kekerasan yang di alami perempuan. Dengan demikian, dapat ditarik benang merah bahwa kkerasan terhadap perempuan hukumnya adalah haram.

\section{Kesimpulan}

Berdasarkan uraian-uraian yang dikemukakan di atas kita melihat dengan membaca ayatayat al-Qur' an yang berbicara tentang kekerasan terhadap perempuan dapat disimpulkan, bahwa sejak awal islam memberikan perhatian yang besar pada pembebasanperempuan dari berbagai tindak kekerasan yang menimpanya. Hampir semua ayat Al-Qur'an yang berbicara tentang kekerasan merupakan reaksi penolakan terhadap praktek yang menistakan perempuan, seperti: praktek adhal dengan segala macam bentuknya, menjadikan perempuan seperti benda yang tidak punya control atas dirinya sendiri, dan sebagainya.

Al-Qur'an sebagai sebuah kitab suci sekaligus yang menjadi salah satu acuan sumber hokum islam menjunjung tinggi nilai norma dan menyelesaikan berbagai kasus bentuk kekerasan, sehingga secara otomatis Al-Qur'an sebagai salah satu sumber hokum islam memandang, bahwa kekerasan terhadap perempuan merupakan suatu tindakan yang melanggar hokum atau syari'at islam serta kekerasan yang telah dilakukan terhadap perempuan hukumnya haram. 


\section{Daftar pustaka}

Al-Qur'anul Karim

Anshori Dadang S. Membincangkan feminism Refleksi Muslimah Atas Peran Sosial Kaum Wanita, cet I; Bandung Pustaka Hidayat, 1997

Abu Dawud, Sunan Abu Dawud, Beirut Dar al-Fikr

Hashem Fuad, Sirah Muhammad Rasulullah, cet. Ke V; Bandung Mizan, 1996

Purnama Siti Ari, dalam Pemahaman Bentuk-Bentuk Tindakan Kekersan Terhadap Perempuan dan Alternatif Pemecahannya, Jakarta Alumni, 2000

Shiham M Quraish, Wawasan Al-Qur'an Tafsir Maudu'I Atas Pelbagai Persoalan U mat cet. II: Bandung Mizan, 1996

Sadli Saparina, Pemahaman Bentuk-Bentuk Tindak Kekerasan Terhadap Perempuan Dan Alternatif Pemecahanny, Jakarta Alumni, 2000 